\title{
PERSEPSI MASYARAKAT TERHADAP KINERJA LEMBAGA KESEHATAN PADA SEKTOR PELAYANAN PENGOBATAN TRADISIONAL DI KABUPATEN PURWAKARTA
}

\author{
Risa Kota Putra ${ }^{*}$, Dewi Ratnasari², Rizki Eka Septiwi ${ }^{3}$ \\ 1,2,3Sekolah Tinggi Ilmu Kesehatan Holistik \\ *Korespondensi: Jl. Veteran No. 272 Ciseureuh Purwakarta, Email: risa@stikesholistic.ac.id
}

\begin{abstract}
ABSTRAK
Latar Belakang: Indonesia memiliki beragam warisan pengobatan tradisional yang potensial untuk dikembangkan, ironinya pasar Indonesia dibanjiri oleh pengobatan tradisional impor asal berbagai negara dari daratan Asia, terutama dari Cina dan India. Pemerintah di bidang regulasi telah cukup memberi landasan hukum, kepastian hukum, pelindungan hukum, peningkatan mutu, keamanan, dan kemanfaatan bagi pelayanan kesehatan tradisional empiris dan pelayanan kesehatan tradisional komplementer. Namun kenyataan implementasinya di kabupaten/kota belum kunjung dirasakan keberpihakan dari lembaga kesehatan terhadap pengobatan tradisional Indonesia tersebut, khususnya di Kabupaten Purwakarta.
\end{abstract}

Tujuan Penelitian: Mengeksplorasi persepsi masyarakat terkait dengan kinerja lembaga kesehatan di bidang pengobatan tradisional berdasarkan keberagaman jenis kelamin, tingkat pendidikan, profesi kesehatan/non-kesehatan dan usia responden.

Metode: Penelitian ini merupakan jenis penelitian eksplanatif asosiatif yang bersifat kualitatif terhadap masyarakat yang terhubung dengan sarana pelayanan kesehatan. Subjek penelitian adalah masyarakat Kabupaten Purwakarta Propinsi Jawa Barat yang berjumlah 137 orang. Pemilihan dan pengambilan sampel menggunakan metode conditional sampling, yang dianalisis menurut skala Ridwan (2009). Pengambilan data menggunakan kuesioner.

Hasil: Hasil penelitian ini menunjukan kinerja lembaga kesehatan di Kabupaten Purwakarta secara eksplanatif asosiatif dipersepsikan lemah pada sektor pengobatan tradisional dengan skore paling tinggi (kuat: 70,35\% atau kumulatif 78\%) pada skala Ridwan (2009) oleh responden wanita berusia dari 40 tahun keatas, pendidikan tidak pernah kuliah, dan berprofesi non-kesehatan, jika dibandingkan terhadap responden dengan kriteria lainnya.

Simpulan: Semua kelompok responden mempersepsikan dengan skore kuat pada skala Ridwan-2009 (62,5\% atau kumulatif 74,0\%) yaitu lemahnya kinerja lembaga kesehatan berdasarkan pada semua variabel yang dinilai secara eksplanatif asosiatif yang mencakup ketidakberpihakan, kelangkaan pendidikan tinggi dan riset, belum terstandarisasi dan pembinaan yang lemah pada sektor pengobatan tradisional di Kabupaten Purwakarta.

Kata kunci: persepsi masyarakat, kinerja lembaga kesehatan, pengobatan tradisional

\begin{abstract}
Background: Indonesia has a variety of traditional medical heritage that has the potential to be developed, ironically the Indonesian market is flooded with imported traditional medicine from various countries from mainland Asia, especially from China and India. Government in the field of regulation has sufficiently provided a legal basis, legal certainty, legal protection, quality improvement, safety, and benefits for traditional empirical health services and complementary traditional health services. But the reality of its implementation in the regency / city has not been felt by the side of the health institutions towards the Indonesian traditional medicine, especially in Purwakarta Regency.

Objective: Exploring public perceptions related to the performance of health institutions in the field of traditional medicine based on gender diversity, education level, health / non-health profession and respondent age.

Method: This research is a type of qualitative associative explanative research in communities that are connected with health care facilities. Subjects were 137 people in Purwakarta Regency, West Java Province. The selection and sampling uses the conditional sampling method, which is analyzed according to the Ridwan scale (2009). Retrieval of data using a questionnaire.
\end{abstract}


Results: The results of this study showed that the performance of health institutions in Purwakarta was explosively associative perceived as weak in the traditional medicine sector with the highest score (strong: $70.35 \%$ or cumulative 78\%) on the Ridwan scale (2009) by female respondents aged 40 years above, education has never gone to college, and is a non-health profession, when compared to respondents with other criteria.

Conclusion: All groups of respondents perceive with a strong score on the Ridwan-2009 scale (62.5\% or cumulative $74.0 \%$ ), namely the weak performance of health institutions based on all variables assessed explosively associative that includes impartiality, scarcity of higher education and research, not yet standardized and weak guidance in the traditional medicine sector in Purwakarta Regency.

Keywords: public perception, performance of health institutions, traditional medicine

\section{PENDAHULUAN}

Lembaga kesehatan dunia (WHO) mendefinisikan, pengobatan tradisional sebagai jumlah total pengetahuan, keterampilan, dan praktik-praktik yang berdasarkan pada teori-teori, keyakinan, dan pengalaman masyarakat yang memiliki adat budaya yang berbeda, baik dijelaskan atau tidak, digunakan dalam pemeliharaan kesehatan serta dalam pencegahan, diagnosa, perbaikan atau pengobatan penyakit secara fisik dan juga mental. Kemajuan di bidang teknologi dan ilmu pengetahuan ternyata tidak mampu begitu saja menghilangkan eksistensi dari pengobatan tradisional ini, hingga faktanya saat ini cara-cara pengobatan tradisional itu tetap hadir di tengah-tengah kehidupan masyarakat, utamanya di pedesaan dan WHO telah menyadarinya $[2,10,12,14,15$, $17,28,32]$

Dewasa ini malah cara-cara pengobatan tradisional ini semakin populer baik di dalam negeri maupun di luar negeri. Riset Oktarlina et. al. (2018), menunjukan sebanyak $80 \%$ penduduk negara berkembang dan $65 \%$ penduduk negara maju memilih menggunakan obat tradisional. Indonesia dengan posisi lima besar dunia akan potensi kekayaan alam tumbuhannya, sekitar $40 \%$ penduduknya menggunakan obat tradisional dan khusus di pedesaan penggunaannya sekitar $70 \%$. Dalam tinjauan lain Indonesia memiliki lebih dari 300 kelompok etnik atau suku bangsa atau tepatnya 1.340 suku bangsa menurut sensus BPS tahun 2010. Setiap kelompok etnik ini paling tidak memiliki 1 (satu) tradisi pengobatan tradisonal, yang relatif berbeda dari kelompok etnik lainnya, meskipun belum diketahui angka pasti jumlah keseluruhan pengobatan tradisional yang pernah berkembang dan telah diwariskan oleh lelulur bumi nusantara ini. Berdasarkan pada jumlah dan keragaman etnik itu saja, layak diyakini bahwa Indonesia adalah bangsa kaya dengan jumlah pengobatan tradisional terbanyak dan beragam yang menyatu dengan kearifan lokal masyarakatnya. Meskipun faktanya demikian, ironinya pasar Indonesia masih saja terus dibanjiri oleh pengobatan tradisional impor dari berbagai negara, terutama dari Cina (Tiongkok), India, Srilangka dan dari kawasan Negaranegara Timur Tengah. $[12,14,15,17,28$, 32]

Pengobatan tradisional seperti di Cina, Ayurveda Hindu, pengobatan Islam Unani Tibbi, dikenal dan didukung oleh pemerintah nasionalnya masing-masing. Bahkan pengobatan Cina secara kuat telah mempengaruhi institusi kesehatan di Korea, Jepang, dan bagian Asia Tenggara lainnya. Ayurveda (yang artinya pengetahuan hidup) sasaran pengaruhnya telah ada di Tibet, Birma, dan Asia Tenggara. Di Negaranegara tersebut, cara pengobatan tradisional dan cara pengobatan modern telah dilakukan secara terpadu dalam sistem pelayanan kesehatan formal, sementara itu di Indonesia cara pengobatan tradisional ini hanya dan masih "dibiarkan" pada tingkat lingkup rumah tangga dan lingkup masyarakat. Dalam hal ini di Indonesia untuk pelayanan kesehatan tingkat pertama, tingkat rujukan pertama dan rujukan yang lebih tinggi dari upaya pelayanan kesehatan secara formal telah diselenggarakan pemerintah melalui fasilitas pelayanan kesehatan kedokteran konvensional (modern), sementara pada tingkat rumah tangga kendali pelayanan kesehatannya dipasrahkan peran 
penentunya kepada individu dan keluarga. $[4,5,7,9,12,22,28,33]$

Pada tahun 2014 Pemerintahan Indonesia telah menerbitkan Peraturan Pemerintah Nomor 103 Tentang Pelayanan Kesehatan Tradisional, yang mengatur tata kelola praktik dan pendidikan bagi pelaku pengobatan tradisional, hanya saja hingga saat ini pada tataran pelaksanaannya di kabupaten/kota belum kunjung terlihat dan terasa nyata. Kontradiktif kenyataan ini ditemukan jawabannya pada penelitian Setyaningsih (2012) bahwa semakin meningkatnya pengetahuan masyarakat tentang pengobatan kedokteran konvensional menyebabkan beralihnya masyarakat ke pengobatan komplementer (kombinasi modern-tradisional) dengan biaya yang lebih terjangkau. Namun seiring dengan kehadiran aneka ragam pengobatan tradisional ini juga menimbulkan prokontra di masyarakat. Karena pengalaman dan informasi yang diterima masyarakat mempengaruhi persepsi dan sikap masyarakat akan pilihan pengobatan bagi diri dan keluarganya. Hal mana menurut penelitian ini persepsi dan sikap masyarakat tentang pengobatan komplementer sebagian besar adalah negative dan terdapat hubungan persepsi dan sikap masyarakat itu terhadap pengobatan komplementer di Kecamatan Grogol Sukoharjo.[23]

Fakta masih banyaknya masyarakat yang masih memilih pengobatan alternatif atau tradisional sebagai langkah untuk menyembuhkan penyakitnya, di samping menggunakan penyembuhan medis, ditemukan alasan bahwa layanan kesehatan alternatif dapat memenuhi kebutuhan kesehatan dari segi sosial, psikologi, dan mungkin pula organik, yang bagi beberapa orang tidak berhasil diperolehnya dari dokter maupun dari pelayanan kesehatan kedokteran konvensional. Kaitan dengan ini sosok dukun dipandang memiliki $\begin{array}{lrr}\text { kemampuan } & \text { tersendiri } & \text { untuk } \\ \text { menyembuhkan } & \text { pasiennya, } & \text { yang }\end{array}$ menggunakan metode yang berbeda dari metode yang digunakan oleh dokter, karena itu keberadaan dukun juga masih berguna bagi masyarakat sekitar.[24]

Bertolak dari latar belakang inilah maka peneliti lebih jauh ingin mengeksplorasi tentang hubungan antara karateristik responden (jenis kelamin, pendidikan, profesi dan usia) dengan persepsi masyarakat terhadap pengobatan tradisional di Kabupaten Purwakarta.

\section{METODE PENELITIAN}

Penelitian ini merupakan penelitian eksplanatif asosiatif yang bersifat kualitatif pada masyarakat yang terhubung dengan pelayanan kesehatan. Data penelitian berupa pilihan responden (subjek) atas pertanyaan/pernyataan kuesioner yang bersifat menjelaskan/merangkan, melalui beberapa pertemuan kelompok masyarakat yang mewakili perkotaan (city), transisi (urban), dan pedesaan (rural) di Kabupaten Purwakarta Propinsi Jawa Barat yang berjumlah 137 orang. Responden meliputi keragaman karakteristik (sebagai variable tetap) yang mencakup jenis kelamin, usia (dibawah 30 tahun; 30 s/d 40 tahun; dan dari 40 tahun keatas), pendidikan (TPK: tidak pernah kuliah; sarjana-S1; dan paskasarjana-S2/S3) dan profesi (non kesehatan dan kesehatan). Pilihan yang mewakili persepsi responden mencakup sangat tidak setuju, tidak setuju, netral, setuju dan sangat setuju sebagai varibel tidak tetap. Pertanyaan kuesioner penelitian yang dipilih responden berasosiasi terhadap kinerja dari lembaga kesehatan. Jumlah atau persentase persepsi responden kemudian diukur menggunakan skala Ridwan, 2009.

\section{HASIL PENELITIAN Karakteristik Responden}


Tabel 1

Distribusi Persepsi Responden Terhadap Belum Optimalnya Kinerja Lembaga Kesehatan pada Sektor Pengobatan Tradisional

\begin{tabular}{|c|c|c|c|c|c|}
\hline \multirow{2}{*}{$\begin{array}{l}\text { Variabel Tetap } \\
\text { (5 pertanyaan) }\end{array}$} & \multicolumn{5}{|c|}{ Variabel Tidak Tetap (Persepsi) } \\
\hline & SS & S & $\mathrm{N}$ & $\mathrm{KS}$ & TS \\
\hline Jumlah rata-rata & 15.8 & 85.6 & 23.4 & 11.2 & 1.0 \\
\hline Persentase & $11.5 \%$ & $62.5 \%$ & $17.1 \%$ & $8.2 \%$ & $0.7 \%$ \\
\hline
\end{tabular}

Data Tabel 1, menunjukan dari 137 responden yang memberikan jawaban pada kuesioner, diketahui $62,5 \%$ (setuju: skala kuat), $11,5 \%$ (sangat setuju: skala sangat lemah) dan nilai kumulatif dari setuju dan sangat setuju 74,0\% (skala kuat). Artinya responden mempersepsikan dengan skala kuat bahwa ketidakberpihakan, kelangkaan pendidikan tinggi dan riset, serta belum terstandarisasi dan terbinanya pengobatan tradisional oleh lembaga kesehatan. Sebaliknya responden yang memberikan nilai persepsi netral hanya sebesar 17,1\% (sangat lemah) dan persepsi kurang setuju dan tidak setuju secara kumulatif hanya sebesar 8,9\% (sangat lemah).

Tabel 1.1

Distribusi Persepsi Responden Terhadap Belum Optimalnya Kinerja Lembaga Kesehatan pada Sektor Pengobatan Tradisional

\begin{tabular}{|c|c|c|c|c|c|c|}
\hline \multirow{2}{*}{$\begin{array}{l}\text { Karakter Responden } \\
\text { Berdasarkan: }\end{array}$} & \multirow{2}{*}{$\begin{array}{c}\mathrm{N} \\
\text { (Jumlah } \\
\text { Responden = } \\
137 \text { orang) }\end{array}$} & \multicolumn{5}{|c|}{$\begin{array}{c}\text { Variabel Tetap (5 pertanyaan) } \\
\text { Variabel Tidak Tetap (\% Persepsi) }\end{array}$} \\
\hline & & SS & S & $\mathrm{N}$ & KS & TS \\
\hline \multicolumn{7}{|l|}{ Jenis kelamin: } \\
\hline Wanita & 111 & $12.4 \%$ & $62.5 \%$ & $16.4 \%$ & $7.7 \%$ & $0.9 \%$ \\
\hline Pria & 26 & $7.7 \%$ & $62.3 \%$ & $20.0 \%$ & $10.0 \%$ & $0.0 \%$ \\
\hline \multicolumn{7}{|l|}{ Usia: } \\
\hline Dari 40 tahun keatas & 45 & $5.8 \%$ & $69.3 \%$ & $15.6 \%$ & $8.0 \%$ & $1.3 \%$ \\
\hline $30 \mathrm{~s} / \mathrm{d} 40$ tahun & 40 & $11.0 \%$ & $60.5 \%$ & $17.5 \%$ & $10.5 \%$ & $0.5 \%$ \\
\hline Dibawah 30 tahun & 52 & $16.9 \%$ & $58.1 \%$ & $18.1 \%$ & $6.5 \%$ & $0.4 \%$ \\
\hline \multicolumn{7}{|l|}{ Pendidikan: } \\
\hline Paskasarjana (S2/S3) & 10 & $20.0 \%$ & $52.0 \%$ & $24.0 \%$ & $2.0 \%$ & $2.0 \%$ \\
\hline Sarjana (S1) & 81 & $14.6 \%$ & $55.8 \%$ & $20.0 \%$ & $8.9 \%$ & $0.7 \%$ \\
\hline TPK & 46 & $4.3 \%$ & $76.5 \%$ & $10.4 \%$ & $8.3 \%$ & $0.4 \%$ \\
\hline \multicolumn{7}{|l|}{ Profesi: } \\
\hline Kesehatan & 85 & $13.6 \%$ & $56.0 \%$ & $21.6 \%$ & $8.2 \%$ & $0.5 \%$ \\
\hline Non Kesehatan & 52 & $8.1 \%$ & $73.1 \%$ & $9.6 \%$ & $8.1 \%$ & $1.2 \%$ \\
\hline
\end{tabular}

Dari 137 responden yang setuju $(62,5 \%)$ dan sangat setuju $(11,5 \%)$ atau kumulatifnya sebesar $74,0 \%$ pada Tabel 1 , ditinjau distribusinya berdasarkan masingmasing kelompok karakter responden pada Tabel 1.1. Berdasarkan jenis kelamin, responden mempersepsikan wanita lebih besar dari pria (setuju, 62,5\%: 62,3\%) atau kumulatif (setuju-sangat setuju, 74,9\% : $70,0 \%)$. Berdasarkan pendidikan, responde
TPK mempersepsikan paling besar dibandingkan terhadap responden sarjana maupun paskasarjana (setuju, $76,5 \%$ : $55,8 \% ; 52,0 \%$ ) atau kumulatif (setujusangat setuju, $80,8 \%: 70,4 \%$ : $72,0 \%$ ). Berdasarkan profesi, responden profesi non-kesehatan mempersepsikan lebih besar dari kesehatan (setuju, 73,1\% : 56,0\%) atau kumulatifnya (setuju-sangat setuju, $81,2 \%$ : $69,6 \%$ ). Berdasarkan usia, responden usia 
dari 40 tahun keatas mempersepsikan paling besar dibandingkan terhadap usia 30-40 tahum maupun usia dibawah 30 tahun (setuju, 69,3\%: 60,5\%; 58,1\%) atau kumulatif (setuju-sangat setuju, 75,1\% : $71,5 \%: 75,0 \%)$. Artinya responden wanita yang berpendidikan SD/SMP/SMA dengan profesi bidang non-kesehatan dan berusia dari 40 tahun keatas mempersepsikan paling besar ketidakberpihakan, kelangkaan pendidikan tinggi dan riset, serta belum terstandarisasi dan terbinanya pengobatan tradisional oleh lembaga kesehatan.

Tabel 1.2

Distribusi Persepsi Responden Terhadap Belum Berpihak Lembaga Kesehatan pada Upaya Sektor Pengobatan Tradisional

\begin{tabular}{|c|c|c|c|c|c|c|}
\hline \multirow{2}{*}{$\begin{array}{l}\text { Karakter Responden } \\
\text { Berdasarkan: }\end{array}$} & \multirow{2}{*}{$\begin{array}{c}\mathrm{N} \\
\text { (Jumlah } \\
\text { Responden = } \\
137 \text { orang) } \\
\end{array}$} & \multicolumn{5}{|c|}{$\frac{\text { Variabel Tetap (2 pertanyaan) }}{\text { Variabel Tidak Tetap (\% Persepsi) }}$} \\
\hline & & SS & $\mathrm{S}$ & $\mathrm{N}$ & KS & $\mathrm{TS}$ \\
\hline \multicolumn{7}{|l|}{ Jenis kelamin: } \\
\hline Wanita & 111 & $7.7 \%$ & $56.3 \%$ & $23.4 \%$ & $11.3 \%$ & $1.4 \%$ \\
\hline Pria & 26 & $5.8 \%$ & $65.4 \%$ & $23.1 \%$ & $5.8 \%$ & $0.0 \%$ \\
\hline \multicolumn{7}{|l|}{ Usia: } \\
\hline Dari 40 tahun keatas & 45 & $3.3 \%$ & $60.0 \%$ & $21.1 \%$ & $13.3 \%$ & $2.2 \%$ \\
\hline $30 \mathrm{~s} / \mathrm{d} 40$ tahun & 40 & $7.5 \%$ & $55.0 \%$ & $22.5 \%$ & $13.8 \%$ & $1.3 \%$ \\
\hline Dibawah 30 tahun & 52 & $10.6 \%$ & $58.7 \%$ & $26.0 \%$ & $4.8 \%$ & $0.0 \%$ \\
\hline \multicolumn{7}{|l|}{ Pendidikan: } \\
\hline Paskasarjana (S2/S3) & 10 & $5.0 \%$ & $60.0 \%$ & $25.0 \%$ & $5.0 \%$ & $5.0 \%$ \\
\hline Sarjana (S1) & 81 & $10.5 \%$ & $51.9 \%$ & $27.2 \%$ & $9.9 \%$ & $0.6 \%$ \\
\hline TPK & 46 & $2.2 \%$ & $68.5 \%$ & $16.3 \%$ & $12.0 \%$ & $1.1 \%$ \\
\hline \multicolumn{7}{|l|}{ Profesi: } \\
\hline Kesehatan & 85 & $9.4 \%$ & $52.4 \%$ & $29.4 \%$ & $8.8 \%$ & $0.0 \%$ \\
\hline Non Keseha & 52 & 3. & $67.3 \%$ & $13.5 \%$ & $\%$ & 2.9 \\
\hline
\end{tabular}

- Persepsi: SS (Sangat Setuju); S (Setuju); N (Netral); KS (Kurang Setuju); TS (Tidak Setuju)

- Scoring: Sangat lemah (0-20); Lemah (21-40); Cukup (41-60); Kuat (61-80); Sangat kuat (81-100), Sumber Ridwan 2009

- TPK (Tidak Pernah Kuliah: SD/SMP/SMA)

Dari 137 responden yang mempersepsikan setuju $(62,5 \%)$ dan sangat setuju $(11,5 \%)$ atau kumulatifnya sebesar $74,0 \%$ pada Tabel 1 , distribusi persepsinya pada variabel kurang mengantisipasi perkembangan dan ketidakberpihakan lembaga kesehatan saja terhadap pengobatan tradisional berdasarkan masing-masing kelompok pada Tabel 1.2. Berdasarkan jenis kelamin, responden pria mempersepsikan lebih besar dari wanita (setuju, 65,4\% : 56,2\%) atau kumulatif (setuju-sangat setuju, $71,2 \%$ : 64,0\%). Berdasarkan pendidikan, responde TPK mempersepsikan paling besar dibandingkan terhadap responden sarjana maupun paskasarjana (setuju, 68,5\% : $51,9 \% ; 60,0 \%$ ) atau kumulatif (setuju- sangat setuju, $70,7 \%: 62,4 \%$ : 65,0\%). Berdasarkan profesi, responden profesi non-kesehatan mempersepsikan lebih besar dari kesehatan (setuju, 67,3\% : 52,4\%) atau kumulatifnya (setuju-sangat setuju, 71,1\% : $61,8 \%$ ). Berdasarkan usia, responden usia dari 40 tahun keatas paling besar dibandingkan terhadap usia 30-40 tahum maupun usia dibawah 30 tahun (setuju, $60,0 \%$ : 55,0\% ; 58,7\%) atau kumulatif (setuju-sangat setuju, 63,3\% : 62,5\% : $69,3 \%$ ). Artinya responden pria berpendidikan SD/SMP/SMA dengan profesi bidang non-kesehatan dan berusia dibawah 30 tahun memberi nilai persepsi paling besar atas ketidakberpihakan lembaga kesehatan kepada pengobatan tradisional.

Tabel 1.3

Distribusi Persepsi Responden Terhadap Kelangkaan Pendidikan Tinggi dan Riset pada Sektor Pengobatan Tradisional

Karakter Responden $\quad \mathrm{N} \quad$ Variabel Tetap (1 pertanyaan)


Berdasarkan:

(Jumlah Responden $=$ 137 orang)

Jenis kelamin:

Pria

Usia:

Dari 40 tahun keatas

$30 \mathrm{~s} / \mathrm{d} 40$ tahun

Dibawah 30 tahun

Pendidikan:

Paskasarjana (S2/S3)

Sarjana (S1)

Tidak pernah kuliah

Profesi:

Kesehatan

Non Kesehatan

$111 \quad 15.3 \%$

$26 \quad 7.7 \%$

Variabel Tidak Tetap (\% Persepsi)

\begin{tabular}{lllll}
\hline SS & S & N & KS & TS \\
\hline
\end{tabular}

- Persepsi: SS (Sangat Setuju); S (Setuju); N (Netral); KS (Kurang Setuju); TS (Tidak Setuju)

- Scoring: Sangat lemah (0-20); Lemah (21-40); Cukup (41-60); Kuat (61-80); Sangat kuat (81-100), Sumber Ridwan 2009

Dari 137 responden yang setuju $(62,5 \%)$ dan sangat setuju $(11,5 \%)$ atau kumulatifnya sebesar $74,0 \%$ pada Tabel 1 , distribusi persepsi khusus terhadap kelangkaan pendidikan tinggi dan riset pengobatan tradisional berdasarkan masing-masing kelompok pada Tabel 1.3. Berdasarkan jenis kelamin, responden wanita lebih besar dari pria (setuju, 69,4\% : $57,7 \%$ ) atau kumulatif (setuju-sangat setuju, $84,7 \%$ : 65,4\%). Berdasarkan pendidikan, responde TPK paling besar dibandingkan terhadap responden sarjana maupun paskasarjana (setuju, 84,8\% : $56,8 \% ; 70,0 \%$ ) atau kumulatif (setujusangat setuju, $87,0 \%: 77,8 \%: 80,0 \%)$.
Berdasarkan profesi, responden profesi non-kesehatan lebih besar dari kesehatan (setuju, 80,8\% : 58,8\%) atau kumulatifnya (setuju-sangat setuju, $86,6 \%$ : 77,6\%). Berdasarkan usia, responden usia dari 40 tahun keatas paling besar dibandingkan terhadap usia 30-40 tahum maupun usia dibawah 30 tahun (setuju, 77,8\% : 70,0\% ; $55,8 \%$ ) atau kumulatif (setuju-sangat setuju, $84,5 \%: 77,5 \%$ : 80,8\%). Artinya responden wanita berpendidikan SD/SMP/SMA dengan profesi bidang nonkesehatan dan berusia dari 40 tahun keatas memberi nilai persepsi paling besar atas kelangkaan pendidikan tinggi dan riset pengobatan tradisional.

Tabel 1.4

Distribusi Persepsi Responden Terhadap Belum Terstandarisasi dan Pembinaan yang Lemah pada Sektor Pengobatan Tradisional

\begin{tabular}{|c|c|c|c|c|c|c|}
\hline \multirow{2}{*}{$\begin{array}{l}\text { Karakter Responden } \\
\text { Berdasarkan: }\end{array}$} & \multirow{2}{*}{$\begin{array}{c}\mathrm{N} \\
\text { (Jumlah } \\
\text { Responden }= \\
137 \text { orang) }\end{array}$} & \multicolumn{5}{|c|}{ Variabel Tetap (2 pertanyaan) } \\
\hline & & SS & $S$ & $\mathrm{~N}$ & KS & $\mathrm{TS}$ \\
\hline \multicolumn{7}{|l|}{ Jenis kelamin: } \\
\hline Wanita & 111 & $15.8 \%$ & $65.3 \%$ & $13.1 \%$ & $5.4 \%$ & $0.5 \%$ \\
\hline Pria & 26 & $9.6 \%$ & $61.5 \%$ & $17.3 \%$ & $11.5 \%$ & $0.0 \%$ \\
\hline \multicolumn{7}{|l|}{ Usia: } \\
\hline Dari 40 tah & 45 & $7.8 \%$ & $74.4 \%$ & $12.2 \%$ & $4.4 \%$ & $1.1 \%$ \\
\hline $30 \mathrm{~s} /$ & 40 & $16.3 \%$ & $61.3 \%$ & $13.8 \%$ & $8.8 \%$ & $0.0 \%$ \\
\hline Dibawah 30 tahun & 52 & $19.2 \%$ & $58.7 \%$ & $15.4 \%$ & $6.7 \%$ & $0.0 \%$ \\
\hline \multicolumn{7}{|l|}{ Pendidikan: } \\
\hline Paskasarjana & 10 & $40.0 \%$ & $35.0 \%$ & $25.0 \%$ & $0.0 \%$ & $0.0 \%$ \\
\hline Sarjana (S1) & 81 & $15.4 \%$ & $59.3 \%$ & $16.0 \%$ & $8.6 \%$ & $0.6 \%$ \\
\hline Tidak pernah kuliah & 46 & $7.6 \%$ & $80.4 \%$ & $7.6 \%$ & $4.3 \%$ & $0.0 \%$ \\
\hline
\end{tabular}

Profesi: 


\begin{tabular}{|c|c|c|c|c|c|c|}
\hline Kesehatan & 85 & $15.3 \%$ & $58.2 \%$ & $17.6 \%$ & $8.2 \%$ & $0.6 \%$ \\
\hline Non Kesehatan & 52 & $13.5 \%$ & $75.0 \%$ & $7.7 \%$ & $3.8 \%$ & $0.0 \%$ \\
\hline
\end{tabular}

Dari 137 responden yang setuju $(62,5 \%)$ dan sangat setuju $(11,5 \%)$ atau kumulatifnya sebesar $74,0 \%$ pada Tabel 4 , diketahui khusus untuk distribusi persepsi yang belum terstandarisasi dan terbinanya pengobatan tradisional berdasarkan masing-masing kelompok pada Tabel 4.4. Berdasarkan jenis kelamin, responden wanita lebih besar dari pria (setuju, 65,3\% : $61,5 \%$ ) atau kumulatif (setuju-sangat setuju, $81,1 \%$ : 71,1\%). Berdasarkan pendidikan, responde TPK paling besar dibandingkan terhadap responden sarjana maupun paskasarjana (setuju, 80,4\% : $59,3 \% ; 35,0 \%$ ) atau kumulatif (setujusangat setuju, 88,0\% : 74,7\% : 75,0\%). Berdasarkan profesi, responden profesi non-kesehatan lebih besar dari kesehatan (setuju, 75,0\% : 58,2\%) atau kumulatifnya (setuju-sangat setuju, $88,5 \%:$ : 73,5\%). Berdasarkan usia, responden usia dari 40 tahun keatas paling besar dibandingkan terhadap usia 30-40 tahum maupun usia dibawah 30 tahun (setuju, 74,4\% : 61,3\% ; $58,7 \%$ ) atau kumulatif (setuju-sangat setuju, $82,2 \%: 77,6 \%: 77,9 \%)$. Artinya responden wanita berpendidikan SD/SMP/SMA dengan profesi bidang nonkesehatan dan berusia dari 40 tahun keatas memberi nilai persepsi paling besar bahwa pengobatan tradisional belum terstandarisasi dan terbina.

\section{PEMBAHASAN}

\section{Karakteristik Responden:}

Tingkah laku manusia dalam menghadapi masalah kesehatan bukanlah suatu tingkah laku yang acak (random behaviour), tetapi suatu tingkah laku yang selektif, terencana, dan terpola dalam suatu sistem kesehatan yang merupakan bagian integral dari budaya masyarakat yang bersangkutan. Tingkah laku yang selektif tersebut merupakan suatu strategi adaptasi sosial-budaya yang timbul sebagai respon terhadap ancaman penyakit. Perilaku tersebut terpola dalam pranata sosial dan tradisi budaya yang ditujukan untuk meningkatkan kesehatan. ${ }^{[6]}$ Persepsi
Menurut Engel, Blackwell, dan Miniard (1995), terdapat lima tahap dalam pengolahan informasi, yaitu pemaparan, perhatian, pemahaman, peneriman, dan retensi. Menurut Young persepsi merupakan aktivitas mengindera, mengintegrasikan dan memberikan penilaian pada obyek-obyek fisik maupun obyek sosial, dan penginderaan tersebut tergantung pada stimulus fisik dan stimulus sosial yang ada di lingkungannya. Sensasisensasi dari lingkungan akan diolah bersama-sama dengan hal-hal yang telah dipelajari sebelumnya baik hal itu berupa harapan-harapan, nilai-nilai, sikap, ingatan dan lain-lain. Proses pengambilan keputusan berawal dari pengenalan kebutuhan yang bisa dimunculkan oleh faktor diri sendiri (internal) maupun faktor di luar diri (eksternal).[20]

Sikap merupakan salah satu variabel penentu dalam pemilihan pengambilan keputusan, tapi bertolak belakang dengan penelitian lain yang menyatakan bahwa sikap hanya berpengaruh $1 \%$ dalam pengambilan keputusan, sedangkan 99\% ditentukan oleh faktor lain. Berbagai faktor yang mempengaruhi pembentukan sikap adalah pengalaman pribadi, kebudayaan, dan orang lain yang dianggap penting. Pembentukan sikap tidak terjadi begitu saja, melainkan sikap terbentuk karena melalui suatu proses tertentu, melalui kontak sosial terus menerus antara individu dengan individu lain disekitarnya demikian pula dalam pengambilan keputusan pengobatan. Sikap merupakan reaksi atau respon yang masih tertutup dari seseorang terhadap stimulus atau objek. Menurut Rosenstock (1974), perilaku individu ditentukan oleh motif dan kepercayaannya, tanpa memperdulikan apakah motif dan kepercayaan tersebut sesuai atau tidak dengan realitas atau pandangan orang lain. Oleh karena itu, perilaku pencarian pengobatan oleh masyarakat dipengaruhi oleh jumlah dan jenis sarana pelayanan kesehatan yang tersedia di sekitarnya. Pada 
wilayah yang banyak tersedia sarana pelayanan kesehatan seperti puskesmas, rumah sakit pemerintah dan swasta, balai pengobatan serta praktek dokter, maka pilihan masyarakat semakin beragam untuk melakukan pencarian pengobatan. ${ }^{[11,13,19]}$

\section{a. Jenis Kelamin Responden}

Sebagian besar responden berjenis kelamin wanita sebanyak 111 orang, sisanya responden berjenis kelamin pria 26 orang. Gibson, Ivancevich, Donnely (1996) menjelaskan bahwa secara umum dari sejak kelahiran, pria dan wanita diperlakukan secara berbeda. Lebih lanjut dijelaskan pula bahwa hasil data riset cukup memastikan sehingga beberapa peneliti percaya adanya perbedaan kreativitas, penalaran dan kemampuan belajar di antara pria dan wanita. Begitu pula dengan sikap dan perilaku yang menunjukkan bahwa laki-laki cenderung lebih kuat dan bertanggung jawab sedangkan wanita sebaliknya lemah. ${ }^{[25]}$ Namun studi-studi psikologi telah menemukan bahwa wanita lebih bersedia untuk mematuhi wewenang dan pria lebih agresif dan lebih besar kemungkinannya daripada wanita dalam memiliki pengharapan untuk sukses. Beberapa ciriciri feminin antara lain pasif, tidak suka spekulasi dan membutuhkan rasa aman, yang berbeda dari maskulin yaitu aktif, sangat suka spekulasi dan tidak sangat membutuhkan rasa aman.[26]

\section{b. Usia Responden}

Berdasarkan pendapat beberapa ahli, semakin bertambah usia seseorang dan semakin banyak pengalaman/hal yang telah dijumpai dan dikerjakannya maka, semakin bijaksana setiap keputusan dan tindakannya. Demikian juga bahwa perbedaan usia konsumen dapat mempengaruhi selera dan kesukaannya terhadap suatu produk.[16, 20]

\section{c. Pendidikan Responden}

Semakin rendahnya tingkat pendidikan maka, semakin tinggi tingkat pengetahuan responden terhadap penggunaan obat tradisional. Demikian juga jika pengetahuan responden tentang obat modern masih rendah maka, responden akan lebih memilih menggunakan obat tradisional yang memang secara langsung telah mereka gunakan secara turun- temurun di lingkungan keluarga. Pola perilaku yang lain meski tidak erat berkorelasi dengan pendidikan, namun dapat diperkirakan rata-rata kecenderungan dari kelompok tidak pernah kuliah (SD/SMP/SMA) yang dapat dicari korelasinya dengan pencarian pengobatan oleh kalangan masyarakat urban cenderung didominasi oleh tindakan self-care termasuk swamedikasi dengan obat moderen dan obat tradisional/herbal; dan kombinasi tindakan antara self-care dan mencari rujukan/konsultasi.[11,17,31,33]

\section{d. Profesi Responden}

Evidence Based Medicine (EBM), juga Evidence Based Practice (EBP) adalah proses meninjau secara sistematis, menilai dan menggunakan temuan penelitian klinis untuk membantu pemberian perawatan klinis yang optimal bagi pasien. EBM bertujuan untuk mengetahui tingkat kepercayaan dari bukti yang ada serta keuntungan dan kerugian dari suatu tindakan (dan tanpa suatu tindakan) dan diagnosa. Kelompok responden profesi kesehatan lekat dengan budaya EBM/EBP yang mensyaratkan setiap pengambilan keputusan dari tindakan profesinya harus berdasarkan kepada bukti-bukti yang sudah teruji dan diakui.[2, 22]

\section{Hubungan Karakter dengan Persepsi Responden Terhadap Kinerja Lembaga Kesehatan di Sektor Pengobatan Tradisional}

Penerbitan Peraturan Pemerintah Nomor 103 Tahun 2014 Tentang Pelayanan Kesehatan Tradisional sudah memberikan landasan hukum, kepastian hukum, pelindungan hukum, peningkatan mutu, keamanan, dan kemanfaatan bagi pelayanan kesehatan tradisional empiris dan pelayanan kesehatan tradisional komplementer. Dengan demikian pada tempatnyalah adanya tuntutan masyarakat terhadap kinerja dari lembaga kesehatan untuk melakukan pembinaan dan pengawasan, terutamanya oleh Pemerintah dan Pemerintah Daerah agar pelayanan kesehatan tradisional empiris dan pelayanan kesehatan tradisional komplementer dapat dipertanggungjawabkan manfaat dan 
keamanannya serta tidak bertentangan dengan norma agama.

Penelitian ini menyajikan hasil yang signifikan bahwa dari 137 responden yang mewakili keberagaman karakter responden yang mencakup jenis kelamin, pendidikan, profesi kesehatan/non kesehatan dan tingkatan usia, mempersepsikan dengan kuat (setuju: 62,5\% atau kumulatif setujusangat setuju: $74,0 \%$ ) atas ketidakberpihakan, kelangkaan pendidikan tinggi dan riset, serta belum terstandarisasi dan terbinanya pengobatan tradisional oleh lembaga kesehatan. Padahal pengobatan tradisional memiliki efek samping yang lebih sedikit dan harga lebih murah dibandingkan pengobatan medis. Data hasil penelitian ini menjawab issue yang melatarbelakangi penelitian ini bahwa meskipun pemerintah Indonesia pada tataran regulasi telah memberi landasan hukum yang kuat kepada pengobatan tradisional, namun belum diimplementasikan oleh aparatur/insan kesehatan pada tingkat yang langsung menyentuh/terhubung dengan para pelaku pengobatan dan masyarakat pengguna secara tepat dan berdampak untuk menjadikan potensi nasional pengobatan tradisional bisa berkembang, bersaing dan teruji serta menjadi tuan rumah di negeri sendiri. ${ }^{[8,11,13,19]}$

Lebih spesifik lagi, alasan-alasan yang dapat melatarbelakangi masih rendahnya kinerja lembaga kesehatan terhadap pengobatan tradisional, dibahas pada dalam hubungannya degan karakterkarakter responden berikut ini:

\section{a. Jenis Kelamin Responden}

Data-data hasil penelitian pada tabel-tabel di atas menunjukan bahwa wanita pada 3 (tiga) kinerja yaitu kinerja secara umum, kelangkaan pendidikan tinggi dan riset, serta belum terstandarisasi dan terbinanya, yang mana wanita mempersepsikan lebih tinggi daripada pria, kecuali pada ketidakberpihakan lembaga kesehatan pria memberi nilai lebih tinggi daripada wanita.

Data penelitian berdasarkan jenis kelamin ini mengungkapkan adanya korelasi yang signifikan antara sikap feminimitas responden wanita yang lebih mendasari pilihan persepsinya pada kebutuhan rasa aman bagi diri dan keluarganya serta bersifat kurang agresif (lebih pasif), dibandingkan terhadap pria. Melalui penelitian ini terlihat jelas bahwa wanita lebih berharap dibandingkan pria agar lembaga kesehatan meningkatkan jaminan terhadap kemanfaatan dan keamanan dari praktik-praktik pengobatan tradisional yang sedang tumbuh menjamur di tengah-tengah masyarakat.[26]

\section{b. Usia Responden}

Semakin bertambah usia seseorang maka, semakin bijaksana dan semakin banyak pengalaman atau hal yang telah dijumpai dan dikerjakan maka, secara otomatis akan menambah pengalaman pribadi seseorang dan akan mempengaruhi level emosionalnya.[13] Kematangan usia dan sikap bijaksana ini sejalan dengan pengalaman yang tergambar pada data persepsi responden yang diberikan pada penelitian ini melalui sebaran kuesioner. Data hasil penelitian menunjukan bahwa kinerja yang ditanyakan kepada responden (kinerja secara umum, kelangkaan pendidikan tinggi dan riset, serta belum terstandarisasi dan terbinanya pengobatan tradisional), responden usia dari 40 tahun keatas selalu memberikan nilai persepsi yang paling tinggi, diikuti responden usia dibawah 30 tahun, dan terendah pada usia 30-40 tahun, kecuali pada kinerja ketidakberpihakan usia dibawah 30 tahun yang paling tinggi. Hal yang menarik dari data adalah bahwa kelompok usia 30-40 tahun, selalu memberikan apresiasinya paling rendah terhadap pengobatan tradisional.

Kematangan dan sikap bijaksana responden kelompok usia dari 40 tahun keatas sejalan dengan pengalamannya, atas potensi besar yang dimiliki bangsa sendiri berupa warisan pengobatan tradisional serta membanjirnya impor pengobatan tradisional terutama dari Cina, India, Srilangka dan beberapa negara lain dari daratan benua Asia, telihat lebih berpengaruh terhadap sikap bijaksana pada kelompok responden berusia yang lebih matang (lebih tua), jika dibandingkan terhadap usia yang lebih muda. Terkait dengan persepsi kelompok usia 30-40 
tahun yang rendah terhadap obat tradisional, dapat dikaitkan dengan ciri pragmatisme kelompok ini terhadap berbagai hal, yang lebih tertarik terhadap segala sesuatu yang instan, serba cepat, praktis dan spesifik, sementara pengobatan tradisional bersifat promotif-preventif, yang mana pengaruhnya baru dapat dilihat dalam jangka panjang dan menyeluruh.

\section{c. Tingkat Pendidikan Responden}

Berdasarkan usia terungkap bahwa responden yang tidak pernah kuliah (TPK: pendidikan SD/SMP/SMA) selalu mempersepsikan paling tinggi terhadap semua kinerja yang dinilai (kinerja secara umum, ketidakberpihakan, kelangkaan pendidikan tinggi dan riset, serta belum terstandarisasi dan terbinanya pengobatan tradisional), dibandingkan kelompok pendidikan S1 maupun pendidikan S2/S3. Hal yang menarik dari data penelitian ini ternyata responden pendidikan S1 selalu memberi nilai paling rendah, artinya responden S1 relatif lebih mengapresiasi kinerja lembaga kesehatan dibandingkan kelompok responden TPK maupun S2/S3.

Hasil penelitian ini sejalan dengan penelitian Jabbar (2016)[11], bahwa tingkat pendidikan yang rendah berkorelasi dengan tingkat pengetahuan responden terhadap penggunaan obat tradisional, hal ini dikarenakan pengetahuan responden tentang obat modern yang masih sangat rendah sehingga lebih memilih menggunakan obat tradisional yang memang secara langsung mereka warisi dan gunakan secara turun-temurun pada lingkungan keluarganya.[17] Dengan demikian penelitian ini mengungkap bahwa tingginya pemanfaatan pengobatan tradisional oleh masyarakat kelompok TPK bukan berdasarkan bukti ilmiah atas manfaat dan keamanan dari pengobatan tradisional, akan tetapi semata-mata atas pengalaman pribadi yang diwarisi keluarga sebagai bagian integral dari budaya masyarakat sekitarnya. Terkait dengan persepsi responden kelompok S1 yang lebih baik dari kelompok TPK dan S2/S3, dapat dimaknai bahwa pengetahuan kelompok S1 yang terbatas (belum dalam) justru memberikan efek skeptis terhadap pengobatan tradisional. Sebaliknya pada
S2/S3 dengan pengetahuannya yang lebih mendalam dan sikap bijak berdampak pada dukungan yang kuat terhadap pengobatan tradisional.

Data penelitian ini juga memberi gambaran bahwa masyarakat terpelajar berpendidikan S1 sebagai bagian terbesar dari pelaku kesehatan di Indonesia, yang harusnya menjadi pelopor dalam pengembangan potensi pengobatan tradisional Indonesia yang kaya dan beragam, terbukti masih belum berhasil diyakinkan oleh lembaga pemerintah melalui program-programnya sejak dari tingkat pusat, propinsi hingga kabupaten/. Data penelitian ini sekaligus mereflesikan bagaimana kinerja lembaga kesehatan di Indonesia hingga saat ini, lain halnya yang dilakukan oleh negara-negara seperti Cina, India, Vietnam dan negara lain di sekitarnya bahwa cara pengobatan tradisional dan cara pengobatan modern telah dilakukan dalam sistem pelayanan kesehatan formal, sementara itu di Indonesia pengobatan tradisional hanya dan masih berperan pada tingkat rumah tangga dan tingkat masyarakat.[27]

\section{d. Profesi Responden}

Berpikir evidence base practice (EBP) dalam mengambil keputusan klinis berdasarkan sumber yang paling relevan dan valid pada profesi kesehatan sudah menjadi keharusan, terlebih pada profesi medik. Oleh karena itu EBP adalah jalan untuk mentransformasikan hasil penelitian ke dalam praktik sehingga setiap profesi kesehatan dapat meningkatkan "quality of care" dari pasien. Konsep EBP ini sudah terintegrasi dalam kurikulum pada setiap program pendidikan tenaga kesehatan, yang mencakup unsur knowledge, skill and attitude. Penerapan evidence base dalam praktik akan menjadi dasar scientific dalam pengambilan keputusan tindakan kesehatan sehingga setiap intervensi yang diberikan dapat dipertanggungjawabkan. Inilah bentuk budaya yang terkesan rigid dalam dunia kesehatan, dan sudah tertanam dalam setiap diri profesi kesehatan sehingga tidak mudah bagi seorang profesional kesehatan untuk dapat menerima begitu saja suatu tindakan kesehatan yang belum berbukti ilmiah, kecuali tindakan tersebut sudah 
jelas mekanisme, pertimbangan risk and benefit, serta fakta-fakta ilmiahnya.

Data pada penelitian berdasarkan atas profesi responden ini sejalan dengan konsep EBP, yang mana responden profesi kesehatan senantiasa memberikan tingkat persepsi yang lebih rendah dari responden kelompok profesi non-kesehatan, terhadap semua kinerja yang dinilai (kinerja secara umum, ketidakberpihakan, kelangkaan pendidikan tinggi dan riset, serta belum terstandarisasi dan terbinanya pengobatan tradisional).

Data-data penelitian ini secara sangat signifikan memberi arti bahwa responden dari kelompok profesi kesehatan belum/kurang dapat menerima kehadiran pengobatan tradisional dibandingkan terhadap kelompok non-kesehatan, sepanjang belum/tidak didukung oleh bukti-bukti ilmiah dari kemanfaatan dan keamanan pengobatan tradisional itu. Padahal praktik-praktik pengobatan tradisional ini di tengah-tengah masyarakat sudah memberikan bukti secara turun temurun dalam rentang waktu yang lebih dari tiga generasi (lebih dari 180 tahun), yang sesungguhnya telah memiliki nilai scientific nyata dan dapat dipertanggungjawabkan. Hanya saja pola pikir evidence base yang sudah tertanam pada diri setiap praktisi kesehatan sulit untuk bermodifikasi terhadap nilai-nilai keilmiahan yang alamiah yang melekat pengobatan tradisional. Oleh karena itu masih diperlukan peningkatan kinerja program dan kegiatan dari lembaga kesehatan, agar keilmiahan alamiah dari pengobatan tradisional bisa ditransformasikan kedalam kaidah konsep evidence base.

\section{SIMPULAN}

Kinerja lembaga kesehatan yang diteliti persepsinya secara eksplanatif asosiatif pada masyarakat (responden) berdasarkan kriteria jenis kelamin, tingkatan usia, tingkatan pendidikan, dan profesi kesehatan/non-kesehatan, yang mencakup persepsi terhadap kinerja ketidakberpihakan, kelangkaan pendidikan tinggi dan riset, belum terstandarisasi dan pembinaan yang lemah pada sektor pengobatan tradisional. Kualifikasi persepsi dinilai menggunakan skala Ridwan (2009) memberikan simpulan sebagai berikut:

1. Untuk semua variable, kinerja lembaga kesehatan dipersepsikan lemah oleh responden kriteria wanita, usia dari 40 tahun keatas, berpendidikan TPK, dan berprofesi non kesehatan dengan skore kuat pada skala Ridwan-2009 (70,35\% atau kumulatif $78 \%$ ).

2. Khusus untuk dua variable (terlambat mengantisipasi perkembangan dan kurang berpihak pada sektor pengobatan tradisional) dipersepsikan lemah oleh responden kriteria pria, usia dibawah 30 tahun, berpendidikan TPK, dan berprofesi non kesehatan dengan skore kuat pada skala Ridwan-2009 (64,98\% atau kumulatif $69,13 \%)$.

3. Khusus untuk variabel langkanya pendidikan tinggi dan riset pada sektor pengobatan tradisional, dipersepsikan lemah bahkan sangat lemah oleh responden kriteria wanita, usia dari 40 tahun keatas, berpendidikan TPK, dan berprofesi non kesehatan dengan skore kuat hingga sangat kuat pada skala Ridwan-2009 (78,2\% atau kumulatif $85,7 \%)$.

4. Khusus untuk dua variable (belum terstandarisasi dan pembinaan yang lemah pada sektor pengobatan tradisional), dipersepsikan lemah bahkan sangat lemah oleh responden kriteria wanita, usia dari 40 tahun keatas, berpendidikan TPK, dan berprofesi non kesehatan dengan skore kuat hingga sangat kuat pada skala Ridwan-2009 (73,78\% atau kumulatif $84,95 \%)$.

Semua kelompok responden mempersepsikan dengan skore kuat pada skala Ridwan-2009 (62,5\% atau kumulatif $74,0 \%$ ) bahwa lemahnya kinerja lembaga kesehatan berdasarkan pada semua variabel yang dinilai secara eksplanatif asosiatif yaitu mencakup ketidakberpihakan, kelangkaan pendidikan tinggi dan riset, belum terstandarisasi dan pembinaan yang lemah pada sektor pengobatan tradisional di Kabupaten Purwakarta. 


\section{DAFTAR PUSTAKA}

1. Akerele, O. (1993), WHO Guidelines for the Assessment of Herbal Medicine. Dalam: Wiryowidagdo (ed). Simposium Penelitian Tumbuhan Obat VII di Ujungpandang 4 - 5 November 1992. PERHIBA: Ujungpandang. 1-60.

2. Azwar, Saifuddin, 2013. Metode Penelitian. Yogyakarta: Pustaka Pelajar

3. Andriati, Wahjudi, R.M.T., Tingkat Penerimaan Penggunaan Jamu sebagai Alternatif Penggunaan Obat Modern pada Masyarakat Ekonomi RendahMenengah dan Atas, Masyarakat, Kebudayaan dan Politik Vol. 29, No. 3, tahun 2016, hal. 133-145.

4. Chang, CY., Leung, TK., Establishment of a Basic Medical Science System or Tradisional Chinese Medicine Education: A Suggestion Based on the Experience Bioceramic Technology, Juornal of Traditional Complememtary of Medicine, 2019.

5. Dermawan, R., Peran Battra dalam Pengobatan Tradisional pada Komunitas Dayak Agabag di Kecamatan Lumbis Kabupaten Nunukan, eJournal Sosiologi Konsentrasi, 2013, 1 (4): 5061 ISSN 0000-0000, ejournal sosiatrisosiologi, 2013.

6. Dunn FL, "Traditional Asian Medicine and Cosmopolitan Medicine as Adaptive System," in Asian Medical System, C. Leslie (ed), Berkeley: University of California Press, 1976.

7. Effendi, M., Pemnafaatan Sistem Pengobatan Tradisional (Battra) di Puskesmas (Studi Deskriptif Mengenai Intensitas Kunjungan dan Efektifitas Sistem Pengobatan Tradisional (Battra) di Puskesmas Gundih Surabaya), Departemen Sosiologi, Fisip, Universitas Airlangga

8. Gitawati R, Handayani RS. Profil Konsumen Obat Tradisional Terhadap Ketanggapan Akan Adanya Efek Samping Obat Tradisional. Buletin Penelitian Sistem Kesehatan, 2006, 11(3); 283-288.

9. Imzastini, NQ., Akulturasi Sistem Medis Tradisional dan Sistem Medis Modern dalam Pengobatan Alternatif Pak Endog di Kabupaten Tuban, Sosiologi dan Antropologi, Fakultas Ilmu Sosial Universitas Negeri Semarang, Skripsi 2016.

10. Ismail, Faktor yang mempengaruhi Keputusan Masyarakat Memilih Obat Tradisiomal di Gampong Lam Ujong, Idea Nursing Journal Vol. VI No. 1 2015 ISSN: 2087-2879.

11. Jabbar, A., Musdalipah, Nurwati, A. Studi Pengetahuan, Sikap dan Tindakan Terhadap Penggunaan Obat Tradisional Bagi Masyarakat di Desa Sabi-Sabila Kecamatan Mowewe Kabupaten Kolaka Timur, Pharmauho Volume 3, No. 1, Hal. 19-22, Majalah Farmasi, Sains, dan Kesehatan, 2016, ISSN 2442-9791

12. Mulyani, H., W.. Sri Harti, E., Indria V., Pengobatan Tradisional Jawa dalam Manuskrip Serat Primbon Jampi Jawi, LITERA, Vol. 16, No. 1, April 2017

13. Kasniyah, N., Fenomena Budaya Dalam Penyembuhan Penyakit Secara Tradisional: Pijat Refleksi dan Transfer Penyakit dengan Media Binatang, Jurnal Masyarakat Kebudayaan dan Politik Tahun 22, Nomor 4: 333-342

14. Kumala LUR. Pemanfaatan Obat Tradisional Dengan Pertimbangan Manfaat dan keamanannya, Majalah Ilmu Kefarmasian, Jakarta, 2003.

15. Murni, SA., Prawito, P., Widiono, S., Eksistensi pemanfaatana tanaman Obat tradisional (TOT) Suku Serawai di Era Medikalisasi Kehidupan, Naturalis, Jurnal Penelitian Pengelolaan Sumber Daya Alam dan Lingkungan, Vol. 1, No. 3, Desember 2012

16. Notoatmodjo. Pengantar Pendidikan Kesehatan dan llmu Perilaku Kesehatan. Yogyakarta, 2003.

17. Oktarlina, RZ., Tarigan, A., Carolia, N., Utami, ER., Hubungan Pengetahuan Keluarga dengan Penggunaan Obat Tradisional di Desa Nunggalrejo Kecamatan Punggur Kabupaten Lampung Tengah, JK Unila, Volume 2, Nomor 1, Februari 2018

18. Pasek, M. S., Satyawan, I. M., Hubungan Persepsi dan Tingkat Pengetahuan Penderita TB dengan Kepatuhan Pengobatan di Kecamatan Buleleng, 
Jurnal Pendidikan Indonesia, Vol. 2, No. 1, April 2013.

19. Rahayu M, Sunarti S, Sulistiarini D, Prawiroatmodjo P. Pemanfaatan Tumbuhan Obat Secara Tradisional Oleh Masyarakat Lokal di Pulau Wawoni, Sulawesi Tenggara, Biodiversitas, 2006, 7(3);245-250

20. Rochaeni, S (2013) Analisis Persepsi, Kesadaran, dan Preferensi Konsumen Terhadap Buah Lokal, Jurnal Agribisnis, Vol. 7, No. 1, Juni 2013.

21. Rosenstock I (1974) Historical Origins of the Health Belief Model.Health Education Monographs Vol. 2 No. 4.

22. Satria, D., Complementary and Alternative Medicine (CAM): Fakta atau Janji?, Idea Nursing Journal

23. Setyaningsih, Y,. Ambarwati, WN., Budinugroho, A., Hubungan Antara Persepsi dengan Sikap Masyarakat terhadap Pengobatan Komplementer di Kecamatan Grogol Kabupaten Sukoharjo, Fakultas Ilmu Kesehatan, Universitas Muhammdyah Surakarta, Surakarta 2012.

24. Setyoningsih, A., Artaria, MD., Pemilihan penyembuhan penyakit melalui pengobatan tradisional non medis atau medis, Masyarakat, Kebudayaan dan Politik Vol. 29, No. 1, tahun 2016, hal. 44-56.

25. Silaya, M. A. (2016) Perbedaan Persepsi Karyawan Berdasarkan Jenis Kelamin Terhadap Tipe Kepemimpinan Transaksional dan Transformasional (Studi pada PT Indofood Sukses Makmur Semarang)

26. Situmorang, NZ., Gaya Kepemimpinan Perempuan, Proceeding PESAT (Psikologi, Ekonomi, Sastra, Arsitektur \& Sipil), Universitas Gunadharma, Vo. IV Oktober, 2011.

27. Soesilo, S. (1996) Peranan Jamu dan Obat Tradisional dalam Pelayanan Kesehatan Masyarakat. Antropologi
Kesehatan Jilid I, Pengobatan Tradisional. Jakarta: Buku Kedokteran BGC.

28. Sumirat, WL., Subagya, S., Rochani, S. (2017), Perilaku Masyarakat pada Pengobatan Tradisional Sangkal Putung H. Atmo Saidi di Desa Sroyo Kecamatan Jaten Kabupaten Karanganyar (Studi Kasus pada Masyarakat Pemakai dan Bukan Pemakai Pengobatan Tradisional Sangkal Putung), Pendidikan Sosiologi Antropologi, Fakultas Keguruan dan Ilmu Pendidikan, Universitas Sebelas Maret, Surakarta.

29. Suryadarma, IGP., Konservasi Tumbuhan Obat Usada Bali dalam Perspektif Ekowisata, Proceeding Seminar Konservasi Tumbuhan Usada Balai dan Perannya dalam Mendukun Ekowisata, 2007.

30. Wicaksena, B., Subekti, NA,. Potensi Pengembangan Pasar Jamu, Peneliti pada Pusat Kebijakan Perdagangan Dalam Negeri.

31. Widayati, A., Health Seeking Behavior di Kalangan Masyarakat Urban di Kota Yogyakarta, Fakultas Farmasi, Universitas Sanata Dharma, Yogyakarta, Jurnal Farmasi Sains dan, November 2012, hlm. 59-65 Vol. 9 No. 2, ISSN: 1693-5683

32. Widiarti, A., Bachri, AA., Husaini, Analisis Pengaruh Faktor Perilaku terhadap Pemanfaatan Kearifan Lokal sebagai Obat Tradisional oleh Masyarakat di Kota Palangkaraya, Jurnal Berkala Kesehatan, Vol. 2, No. 1, Nov 2016: 30-40

33. Widowati, L., Siswanto, Delima, Siswoyo, H., Evaluasi Praktik Dokter yang Meresepkan Jamu untuk Pasien Penderita Penyakit Degenerative di 12 Propinsi, Media Litbangkes Vol. 24 No. 2, Juni 2014, 95-102 